Articles from 2013 and after

are now only accessible on

the Chicago Journals website at JOURMALS.UCHIGABO.EDU

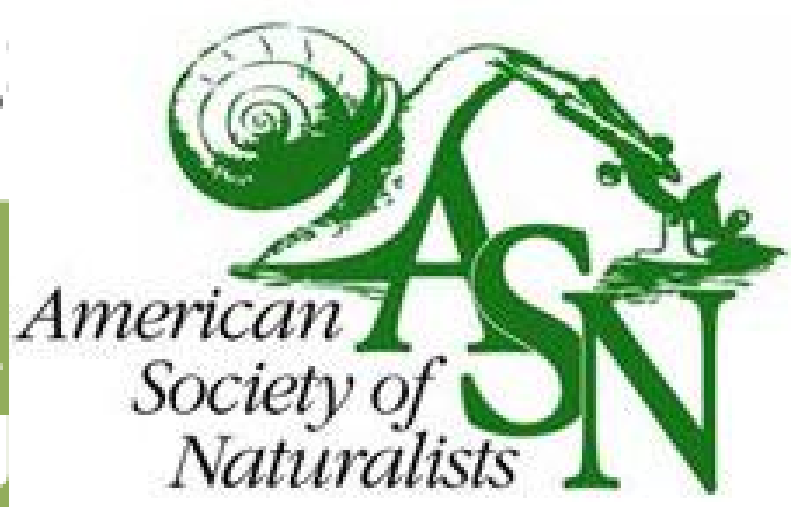

Evolution of Abilities to Regenerate Neurons in Central Nervous Systems Author(s): C. E. Hulsebosch and G. D. Bittner

Source: The American Naturalist, Vol. 115, No. 2 (Feb., 1980), pp. 276-284

Published by: The University of Chicago Press for The American Society of Naturalists Stable URL: http://www.jstor.org/stable/2460598

Accessed: 31-05-2016 17:00 UTC

Your use of the JSTOR archive indicates your acceptance of the Terms \& Conditions of Use, available at

http://about.jstor.org/terms

JSTOR is a not-for-profit service that helps scholars, researchers, and students discover, use, and build upon a wide range of content in a trusted digital archive. We use information technology and tools to increase productivity and facilitate new forms of scholarship. For more information about JSTOR, please contact support@jstor.org.

The University of Chicago Press, The American Society of Naturalists are collaborating with JSTOR to digitize, preserve and extend access to The American Naturalist 


\title{
EVOLUTION OF ABILITIES TO REGENERATE NEURONS IN CENTRAL NERVOUS SYSTEMS
}

\author{
C. E. Hulsebosch and G. D. Bittner
}

Department of Zoology, University of Texas, Austin, Texas 78712

Submitted October 21, 1977; Accepted September 22, 1978

The ability to regenerate complex body parts (those composed of several tissue types) or to regenerate injured tissue is differentially distributed among metazoans. For example, some arthropods and some amphibians can regenerate appendages, but birds and mammals cannot. Present explanations for these observed differences in regenerative ability state that the regenerative capacity is influenced by environmental conditions of the species habitat (Needham 1961) and/or that the capacity to regenerate contributes favorably to reproductive efficacy and consequently is the result of selection (Barr 1964). Furthermore, certain physiological and anatomical adaptations could predispose a species for selection of a particular regenerative mechanism. For example, differences in the regenerative abilities of arthropods and mammals might be accounted for not only by the species' environment but also by anatomical structures. The crayfish has much of its body mass supported by the surrounding aquatic medium and also has numerous appendages and a powerful tail used in escape. The loss of one or a few appendages would not hamper the movement of the crayfish nearly as much as the loss of one or two appendages would affect the ability of the rat to escape predation. Thus, the loss of an appendage in the rat may be synonymous with a lethal injury. Therefore, the environmental conditions and the preexisting number and structure of appendages may well have contributed to the differential ability of the crayfish and the rat to regenerate limbs.

Using the same reasoning with respect to regeneration at the tissue level, limb musculature is more exposed to injury in mammals than in arthropods, in which the musculature is protected by exoskeleton. Consequently, the frequency of injuries to limb musculature alone might be higher in the rat than the crayfish. For this reason selection for regeneration of limb musculature may have been greater in the rat than the crayfish. In fact, the rat does regenerate muscle masses (Carlson 1968, 1974; Snow 1973), whereas the crayfish shows little or no muscle regeneration following selective injury to that tissue (G. D. Bittner and R. D. Moe, unpublished data).

In addition to anatomical structures, other physiological and cellular factors such as the type of circulatory system (open vs. closed), the humoral substances present, and the capacity for cell mitosis, could all influence the evolution of 
regenerative capacity in a given species. Few arguments for selection of regeneration in terms of physiological factors have been proposed. This paper will discuss how one physiological mechanism in reproductively competent metazoans might affect the distribution of regenerative capacity following injury or ablation of one particular tissue, that of the central nervous system (CNS). We will discuss only regeneration of selectively damaged CNS tissue and not regeneration of CNS tissue within an entire regenerating body part. (In considering differential regenerative responses, it is important to note that the regenerative capacity of a specific tissue cannot be predicted a priori based on the regenerative capacity of the body part in which the tissue resides. For example, an injured tissue in a limb capable of regenerating will not necessarily regenerate $[G$. D. Bittner and R. D. Moe, unpublished data].)

\section{RESPONSE TO CNS INJURY}

Unlike any other tissue, the normal function of CNS tissue depends upon highly specific cell-to-cell interactions. Hence, restoration of original function after injury to CNS tissue must entail regeneration of new neurons in appropriate numbers, which then must develop proper connections.

The ability to generate new CNS neurons in response to injury involving the loss of cell bodies is relatively rare in adult (reproductively competent) organisms. However, since different authors have used various techniques and organisms to study regeneration, it is difficult to compare results in this field. Furthermore, given the rather limited number of studies, it may be fallacious to interpret every positive report as evidence of regeneration and every negative report as evidence for the lack of regenerative ability. Nevertheless, it seems to us that adult mammals and birds show little or no ability to generate CNS neurons in response to injury (Clearwaters 1954; Altman 1962; Clemente 1964; Guth and Windle 1973; Guth 1975). Two classes examined in arthropods also do not exhibit significant neuron regeneration. Among insects, adult cockroaches (Periplaneta americana) are unable to regenerate ablated abdominal ganglia within one molt (Bodenstein 1957); and in crustaceans adult crayfish (Procambarus clarkii) show no CNS cell replacement within $1 \mathrm{yr}$ after ablation of an abdominal ganglion (Bittner et al. 1974).

In other taxonomic groups the ability to replace injured neurons varies even among closely related species and, in a given species, CNS regenerative abilities may be restricted to specific regions. For example, among the teleosts regeneration of the telencephalon in adult sticklebacks, Gasterosteus aculeatus (Segaar 1961, 1965), and of the optic tectum of caruscian carp, Carassius carassius (Kirsche and Kirsche 1961), have been shown using both histological and behavioral criteria. However, adult goldfish C. auratus are not able to regenerate injured or ablated portions of the telencephalon (Bernstein 1967) or retinal ganglion cells (Schmidt et al. 1978) but can regenerate photoreceptors (Schmidt et al. 1978). Adult salamanders (Stone 1959) and adult newts (Stone 1950; Keefe 1973), both urodeles, can regenerate retinal ganglion cells and photoreceptors which are diencephalon anlage. Furthermore, adult newts are able to replace ablated neu- 
rons of the spinal cord on the postbrachial region (Butler and Ward 1967), but are unable to regenerate ablated portions of the telencephalon (Piatt 1955a). Among anurans, adult Xenopus can regenerate excised regions of the telencephalon (Jordan 1958; Kosciuszko 1958), but no regeneration of retinal ganglion cells has been demonstrated in Xenopus or any other anuran (Gaze 1970).

In the absence of body-part regeneration, regeneration of CNS neurons in the invertebrates has been demonstrated only in some species of the phylum Annelida. For example, histological replacement of nerve cell bodies occurs in various species of earthworms such as Lumbricus terrestris (Schwartz 1932), Allolobophora caliginosa (Kortisanszky and Hartwig 1974), Eisenia foetida (Herlant-Meewis and Deligne 1965), and Helodrilus caliginosa (Hall 1921). Our laboratory (Birse and Bittner 1976, 1977) has recently confirmed these results. However, we have also shown that several species of leeches (Hirudo medicinalis, Haemopis grande, and Macrobdella) do not regenerate neural somata and never correct behavioral deficits in a series of rigorous experiments which include ganglionic ablations similar to that performed on earthworms by Birse and Bittner (1977), in addition to quarter ganglionic ablations and the removal of two neuronal somata (Hulsebosch and Bittner 1978).

Other mechanisms have evolved for the partial restitution of function resulting from CNS injury in species which do not regenerate neurons. For instance, in adult mammals, surviving neurons can rearrange their synaptic contacts (Liu and Chambers 1958; Steward et al. 1974; Raisman 1975). Also, neuronal processes have been shown to grow across the lesion site (perhaps in an attempt to reestablish original synaptic connections) in vertebrates (Koppanyi 1955; Piatt 1955b; Adams et al. 1969; Bernstein and Gelderd 1970), as well as in invertebrates (Boulton 1969; Edwards and Palka 1971; Frank et al. 1975) which do not produce new CNS neurons in response to injury. In fact, adult organisms which generate new neurons may also show growth and/or rearrangement of neuronal processes following injury (Birse and Bittner 1976, 1977).

In certain cases, prevention of degeneration of severed axons may allow an organism to survive and reproduce even in the absence of regeneration. For example, the severed processes of many giant and nongiant neurons in the ventral nerve cord of the crayfish, Procambarus clarkii, continue to mediate locally generated reflexes for many months. Several female crayfish with transected cords have even mated and successfully hatched one or more sets of eggs (Bittner 1977). Another example of this phenomenon occurs in the leech, in which the severed axon of a heart interneuron continues to conduct impulses for several weeks after separation from its soma (Calabrese 1977). In these species, adaptations for very long term survival (up to $1 \mathrm{yr}$ ) of severed processes allow certain neurons to continue to mediate many important reflexes and hence to compensate for the lack of neuron regeneration or synaptic rearrangement (Wine 1973; Bittner et al. 1974; Bittner 1977; Meyer and Bittner 1978a, 1978b). However, normal CNS function is not achieved when the original neurons are not replaced.

\section{EVOLUTION AND CNS REGENERATION}

One theory postulated to account for the differential distribution of regeneration is that the ability to regenerate any tissue (or body part) decreases with increasing 
phylogenetic evolution. In other words, as organisms evolve more complex tissues and organs, regeneration is less likely (Huxley 1942; Needham 1952; Maron 1959; Hibbard 1963; Goss 1969).

This correlation may hold with respect to the distribution of CNS regeneration involving the replacement of ablated neurons. The phylum Arthropoda is considered phylogenetically more advanced than Annelida, and many species of oligochaetes regenerate neural somata. Furthermore, among annelids, the class Hirudinea (leeches) is often considered the most specialized and therefore might not be expected to regenerate neurons. However, it is difficult, if not impossible, to determine which species are more primitive phylogenetically or which arose the earliest in evolutionary history. For example, even among the vertebrates, there is no evidence that teleosts are more primitive than amphibians (Koppanyi 1955; Grant 1963; Segaar 1965). Hence their ability to regenerate CNS cell bodies more successfully than amphibians cannot be attributed merely to their supposedly "lower" phylogenetic status.

In addition, any increase in tissue complexity in the CNS is difficult to demonstrate, if by tissue complexity one is referring to cellular interactions. In fact, the general nature and cellular mechanisms of bioelectric phenomena in vertebrate and invertebrate neurons are very similar (Bullock and Horridge 1965). Throughout the entire animal kingdom there appears to be a conservative evolution of basic neuronal properties, such as the mechanisms for axonal conduction of spikes and synaptic transmission by release of transmitter substances or electrotonic gap junctions. Therefore, the basic mechanisms of neuronal interactions in the central nervous system are similar for both invertebrates and vertebrates (Bittner 1977).

On the other hand, if one measures complexity in terms of the total number of neurons in the CNS, then the phylogenetic status may correlate with CNS regenerative capacity in vertebrates. For example, various amphibians and teleosts can replace ablated CNS cell bodies and also have fewer neurons than mammals, which show no CNS neuron regeneration. However, this correlation does not apply when comparing invertebrates with vertebrates. Leeches, cockroaches, and crayfish cannot replace injured neurons and certainly have fewer CNS neurons than urodeles, anurans, and teleosts (Jacobson 1978), which do regenerate neurons. Furthermore, this correlation does not hold even among the invertebrates. The earthworm has a greater total number of neurons and a greater number in each ganglion than the leech (Ogawa 1928; C. Hulsebosch, unpublished data), but only the former is able to replace ablated neurons or ganglia.

It might be possible by other hypotheses to account for the fact that the ability to regenerate neurons not only varies from class to class, as among annelids, but varies within a class, as in teleosts, and may vary in different regions in the CNS of the same species. For instance, in nature certain types of sublethal injuries might occur to specific portions of the CNS with such a high frequency that selection for neural regeneration would be intense. Concomitantly, anatomical and/or physiological adaptations might influence the selection for certain regenerative mechanisms. For example, the stiff exoskeleton of arthropods probably reduces the frequency of neural damage from external predators, but not from parasites or disease. Perhaps the absence of CNS regeneration in arthropods is a 
result of the protective exoskeleton. On the other hand, parasitic infection or disease may have directed selection toward an alternative response to neural trauma, i.e., the long-term survival of severed CNS axonal processes evident in crustaceans (Wine 1973; Bittner et al. 1974; Meyer and Bittner 1978a, 1978b).

One might predict regenerative abilities to be high in a tissue which is not only capable of adding cells but does so normally in the adult. In mammals, for instance, certain exocrine glands such as pancreas and salivary glands, add new secretory acini under appropriate physiological conditions and can also regenerate following partial ablation (Goss 1966). Certainly those species which add neurons throughout ontogeny have ongoing processes (mitosis and/or redifferentiation) whereby new neurons are added. In these species an injury or ablation to the CNS of an organism could stimulate or accelerate an ongoing process. Furthermore, all tissues at some early stage of development often have a higher regenerative capacity than adult tissues. In fact, in larval forms of urodeles (Holtzer 1951; Butler and Ward 1965), anurans (Srebro 1959), and aves (Clearwaters 1954; Hamburger 1955; Clemente 1964) ablated nerve cells are regenerated, whereas this ability is very poorly developed or nonexistent in adults.

One might predict that those species which add CNS neurons during ontogeny are more likely to regenerate neural cells in response to injury or disease than those species which do not normally add neurons. In fact, this correlation of neuronal addition with regeneration of nerve cell bodies is consistently observed among contemporary species. For example, mammals (Altman 1962; Altman and Das 1965; Palehaev 1972; Jacobson 1978), insects (Power 1952; Needham 1965; Gymer and Edwards 1967; Goodman 1976), crustaceans (Bullock and Horridge 1965; c.f. Roth and Suppes 1973), and leeches (Jansen and Nicholls 1972; Lent 1977) do not add many, if any, CNS neurons during ontogeny and have little or no ability to regenerate ablated cell bodies. In contrast, certain teleosts (Kirsche and Kirsche 1961; Johns and Easter 1975, 1977) and most oligochaetes (Beddard 1895; Berril 1952; Goss 1969) have been reported to add CNS neurons during ontogeny and also to regenerate ablated CNS neurons.

It is quite possible that CNS neuronal addition in an adult species may occur only in a specific region of the neuraxis. In these species the ability to regenerate neurons in response to small ablations to that specific region should be higher than in regions where no new neurons are added. For example, goldfish retinae grow by cell addition throughout adult life (Johns and Easter 1975, 1977) and can regenerate retinal cells (Schmidt et al. 1978). Furthermore, primary olfactory neurons probably of neural crest origin (Balinsky 1970) in mammals are constantly renewed in the adult and do regenerate (Harding et al. 1977).

The correlation of CNS regeneration and CNS neuronal addition in the adult can be explained in evolutionary terms as well as mechanistic terms. Embryological development and regeneration of neural tissue have several common phenomena: cell division, development and growth of nerve axons and dendrites, and formation of appropriate cell-to-cell connections. In fact, some authors have argued that the genetic information which codes for embryonic development would suffice for regeneration (Spilsbury 1961; Barr 1964). Selection of a set of factors which prolonged the expression of the genes responsible for a develop- 
mental process or allowed their reexpression later in ontogeny could provide genetic information necessary for the expression of regeneration.

The conditions in nature which could select for continual addition of neurons in the adult are speculative at best. However, there should be variation of CNS neuron addition abilities within taxonomic groups which relates in some manner to the differences in environmental and life histories between the various species and this should correlate, in turn, with the ability to regenerate CNS cell bodies. Utilizing $\mathrm{H}^{3}$-thymidine radio-labeling techniques or neuron-counting techniques, it should be possible to determine if the number of CNS neurons increases significantly in normal uninjured adults of a given species. Furthermore, those species which add neurons during ontogeny to a given portion of the CNS should demonstrate an ability to regenerate neurons in response to ablation of CNS cell bodies in that same region.

In conclusion, the selection for regeneration in general and CNS regeneration in particular appears to be influenced by the natural environment of the species as well as by the species anatomy and cellular physiology. We propose that the normal addition of CNS nerve cell bodies has had a major influence on the ability of metazoans to replace ablated CNS neurons, and that experiments can determine the validity of this hypothesis.

\section{SUMMARY}

Several hypotheses have been presented to account for the differential distribution of tissue regeneration in metazoans. The influence of the environmental conditions of the species habitat (Needham 1961) and the possible contribution of regeneration to reproductive efficiency (Barr 1964) have been suggested to play a major determinant in the selection for regeneration. In addition to these factors, certain physiological and anatomical adaptations may contribute to the evolution of specific regenerative mechanisms in a given species. We present evidence which suggests that an ability to add neurons to normal central nervous systems in reproductively competent metazoans is a major influence in the evolution of an ability to regenerate ablated neurons.

\section{ACKNOWLEDGMENTS}

We are very grateful to Verne Grant, Helen Pianka, and Larry Gilbert for invaluable criticisms of the manuscript. This work was supported by a Kappa Kappa Gamma Graduate Fellowship Award to C. E. H. and NIH grant NS-11861 and RCDA NS-00070 to G. D. B.

\section{LITERATURE CITED}

Adams, J. H., P. M. Dancel, and M. L. Prichard. 1969. Degeneration and regeneration of hypothalamic nerve fibers in the neurohypophysis after pituitary stalk section in the ferret. J. Comp. Neurol. 135:121-144.

Altman, J. 1962. Are new neurons formed in the brains of adult mammals? Science. 135:1127-1128. 
Altman, J., and G. D. Das. 1965. Autoradiographic and histological evidence of postnatal hippocampal neurogenesis in rats. J. Comp. Neurol. 124:319-336.

Balinsky, B. I. 1970. An introduction to embryology. Saunders, Philadelphia.

Barr, H. J. 1964. Regeneration and natural selection. Am. Nat. 118:183-186.

Beddard, F. E. 1895. A monograph of the order of Oligochaeta. Clarendon, Oxford.

Bernstein, J. J. 1967. The regenerative capacity of the telencephalon of the goldfish and the rat. Exp. Neurol. 17:44-56.

Bernstein, J. J., and J. Gelderd. 1970. Regeneration of the long spinal tracts in the goldfish. Brain Res. 20:33-38.

Berrill, N. J. 1952. Regeneration and budding in worms. Biol. Rev. 27:401-438.

Birse, S., and G. D. Bittner. 1976. Regeneration of giant axons in earthworms. Brain Res. 113:575581.

1977. Regeneration of giant axons in earthworms. Fed. Proc. 36:554.

Bittner, G. D. 1977. Trophic interactions of crustacean neurons. Pages 507-532 in G. Hoyle, ed. Identified neurons and behavior. Plenum, New York.

Bittner, G. D., M. L. Ballinger, and J. L. Larimer. 1974. Crayfish CNS. Minimal degenerativeregenerative changes after lesioning. J. Exp. Zool. 189:13-36.

Bodenstein, D. 1957. Studies of nerve regeneration in Periplaneta americana. J. Exp. Zool. 136:89115.

Boulton, D. 1969. Degeneration and regeneration in the insect nervous system. Int. Z. Zellforsch. 101:98-118.

Bullock, T. H., and G. A. Horridge. 1965. Structure and function in the nervous systems of invertebrates. Freeman, San Francisco.

Butler, E. G., and M. B. Ward. 1965. Reconstitution of the spinal cord following ablation in urodele larvae. J. Exp. Zool. 160:47-66.

1967. Reconstitution of the spinal cord after ablation in adult Triturus. Dev. Biol. 15:464-486.

Calabrese, R. L. 1977. Regeneration of an intersegmental interneuron in the leech. Soc. Neurosci. 3:102.

Carlson, B. M. 1968. Regeneration of the completely excised gastrocnemius muscle in frog and rat from minced muscle fragments. J. Morph. 125:447-472.

1974. Regeneration from short stumps of rat gastrocnemius muscle. Experientia (Basel) 30:275-276.

Clearwaters, K. P. 1954. Regeneration of the spinal cord of the chick. J. Comp. Neurol. 101:317329.

Clemente, C. D. 1964. Regeneration in the vertebrate central nervous system. Int. Rev. Neurobiol. 6:257-301.

Edwards, J. S., and J. Palka. 1971. Neural regeneration: delayed formation of central contracts by insect sensory cells. Science 172:591-594.

Frank, E., J. K. S. Jansen, and E. Rinvik. 1975. A multisomatic axon in the central nervous system of the leech. J. Comp. Neurol. 159:1-14.

Gaze, R. M. 1970. The formation of nerve connections. Academic Press, London.

Goodman, C. 1976. Constancy and uniqueness in a large population of small interneurons. Science 193:502-504.

Goss, R. J. 1966. Hypertrophy versus hyperplasia. Science 153:1615-1620. 1969. Principles of regeneration. Academic Press, New York.

Grant, V. 1963. The origin of adaptations. Columbia University Press, New York.

Guth, L. 1975. History of central nervous system regeneration research. Exp. Neurol. 48:3-15.

Guth, L., and W. F. Windle. 1973. Physiological, molecular, and genetic aspects of central nervous system regeneration. Exp. Neurol. 39:3-16.

Gymer, A., and J. S. Edwards. 1967. The development of the insect nervous system I. An analysis of postembryonic growth in terminal ganglia of Acheta domesticus. J. Morphol. 123:191-198.

Hall, A. R. 1921. Regeneration in the annelid nerve cord. J. Comp. Neurol. 33:163-177.

Hamburger, V. 1955. Regeneration in the central nervous systems of reptiles and of birds. Pages 47-53 in W. F. Windle, ed. Regeneration in the central nervous system. Bannerstone, Sprinfield, Ill.

Harding, J., P. P. C. Graziadi, G. A. M. Graziadi, and F. L. Margolis. 1977. Denervation in the 
primary olfactory pathway of mice. IV. Biochemical and morphological evidence for neuronal replacement following nerve section. Brain Res. 132:11-28.

Herlant-Meewis, H., and J. Deligne. 1965. Influence of the nervous system on regeneration in annelids. Pages 228-239 in V. Kiortsis and H. A. L. Trampusch, eds. Regeneration in animals and related problems. North-Holland, Amsterdam.

Hibbard, E. 1963. Regeneration in the severed spinal cord of the chordate larvae of Petromyzon marinus. Exp. Neurol. 7:175-185.

Holtzer, H. 1951. Reconstitution of the urodele spinal cord following unilateral ablation. I. Chronology of neuron regulation. J. Exp. Zool. 117:523-558.

Hulsebosch, C. E., and G. D. Bittner. 1978. A comparative study of CNS regenerative abilities. Soc. Neurosci. 4:532.

Huxley, J. 1942. Evolution--the modern synthesis. Allen \& University, London.

Jacobson, M. 1978. Developmental neurobiology. Holt, Rhinehart \& Winston, New York.

Jansen, J. D. S., and J. G. Nicholls. 1972. Regeneration and changes in synaptic connections between individual nerve cells in the central nervous system of the leech. Proc. Natl. Acad. Sci. USA 69:636-639.

Johns, P. R., and S. S. Easter. 1975. Retinal growth in adult goldfish. Pages 451-457 in M. A. Ali, ed. Vision in fishes: new approaches in research. Plenum, New York.

- 1977. Growth of the adult goldfish eye. II. Increase in retinal cell number. J. Comp. Neurol. 176:331-342.

Jordan, M. 1958. Regeneration of the endbrain in postmetamorphic Xenopus laevis. Folia Biol. (Cracow) 6:103-116.

Keefe, J. R. 1973. An analysis of urodelian retinal regeneration. J. Exp. Zool. 184:185-206.

Kirsche, W., and K. Kirsche. 1961. Experimentalle Untersuchungen zur Frage der Regeneration und Funktion des Tectum opticum von Carassius carassius L. Z. Mikrosk. Anat. Forsch. (Leipz.) 67:140-182.

Koppanyi, T. 1955. Regeneration in the central nervous system of fishes. Pages 3-19 in W. F. Windle, ed. Regeneration in the central nervous system. Bannerstone, Springfield, Ill.

Koritsanszky, S., and H. G. Hartwig. 1974. The regeneration of the monoaminergic system in the cerebral ganglion of the earthworm (Allolobophora caliginosa) Cell Tissue Res. 151:171-186.

Kosciuszko, H. 1958. The influence of the olfactory nerves on the regeneration of the endbrain in Xenopus laevis tadpoles. Folia Biol. (Cracow) 6:117-130.

Lent, C. M. 1977. The Retzius cells within the central nervous system of leeches. Prog. Neurobiol. 8:81-117.

Liu, C., and W. Chambers. 1958. Intraspinal sprouting of dorsal root axons. Arch. Neurol. Psychiat. 79:46-61.

Maron, K. 1959. Regeneration capacity of the spinal cord in Lampetra fluviatilis larvae. Folia Biol. (Cracow) 7:179-189.

Meyer, M. R., and G. D. Bittner. 1978a . Biochemical studies of trophic interactions in crayfish giant axons. Brain Res. (in press).

$1978 b$. Histological studies of trophic interactions in crayfish giant axons. Brain Res. (in press).

Needham, A. E. 1952. Regeneration and wound healing. Wiley, New York.

1961. Evolution of regeneration and its possible bearing on philosophy. Nature (Lond.) 192:1255-1256.

1965. Regeneration in the arthropoda and its endocrine control. Pages 283-323 in V. Kiortsis and H. A. L. Trampusch, eds. Regeneration in animals and related problems. North-Holland, Amsterdam.

Ogawa, F. 1928. On the number of ganglion cells and nerve fibers in some of the ventral nerve cords of the earthworm. I. The number of ganglion cells. Sci. Rep. Tohoku Univ. Fourth Ser. (Biol.) 3:745-756.

Palehaev, L. V. 1972. Loss and restoration of regenerative capacity in tissues and organs of animals. Harvard University Press, Cambridge, Mass.

Piatt, J. 1955a. Regeneration in the central nervous system of Amphibia. Pages 20-46 in W. F. Windle, ed. Regeneration in the central nervous system. Bannerstone, Springfield, Ill. 
1955b. Regeneration of the spinal cord in the salamander. J. Exp. Zool. 129:177-207.

Power, M. E. 1952. A quantitative study of the growth of the central nervous system of a holometabolous insect Drosophila melanogaster. J. Morphol. 91:389-411.

Raisman, G. 1975. Neuronal plasticity in the septal nuclei. Pages 295-298 in M. Santini, ed. Golgi centennial symposium proceedings. Raven, New York.

Roth, R. R., and P. Suppes. 1973. Postembryonic addition of neurons to the abdominal nerve cord of the crayfish. Anat. Rec. 175:430.

Schmidt, J. T., C. M. Cicerone, and S. S. Easter. 1978. Expansion of the half retinal projection to the tectum in the goldfish: an electrophysiological and anatomical study. J. Comp. Neurol. 177:257-278.

Schwartz, H. G. 1932. Studies in the regeneration of central nervous tissue. I. Origin of nerve cells in regenerated cerebral ganglia in the earthworm. J. Comp. Neurol. 55:545-571.

Segaar, J. 1961. Telencephalon and behavior in Gasterosteus aculeatus. Behavior 18:256-287.

. 1965. Behavioral aspects of degeneration and regeneration in fish brain: a comparison with higher vertebrates. Prog. Brain Res. 14:143-231.

Snow, M. H. 1973. Metabolic activity during the degenerative and early regenerative stages of minced skeletal muscle. Anat. Rec. 176:185-204.

Spilsbury, R. J. 1961. Evolution of regeneration and its possible bearing on philosophy. Nature (Lond.) 192:1254-1255.

Srebro, Z. 1959. Investigations on the regenerative capacity of the between-brain and the influence of its removal upon the development of Xenopus laevis tadpoles. Folia Biol. (Cracow) 7:191202.

Steward, O., C. W. Cotman, and G. S. Lynch. 1974. Growth of a new fiber projection in the brain of adult rats: re-innervation of the dentate gyrus by the contralateral entorhinal cortex following ipsi-lateral entorhinal lesion. Exp. Brain Res. 20:45-66.

Stone, L. S. 1950. The role of retinal pigment cells in regenerating neural retinae of adult salamander eyes. J. Exp. Zool. 113:9-32.

1959. Experiments testing the capacity of the iris to regenerate neural retina in eyes of adult newts. J. Exp. Zool. 142:285-308.

Wine, J. J. 1973. Invertebrate central neurons: orthograde degeneration and retrograde changes after axonotomy. Exp. Neurol. 38:157-169. 